\title{
Virtual Visits as a Learning Tool for Historical Heritage in Two Specific Examples: Évora and Mérida ${ }^{\dagger}$
}

\author{
Mario Corrales-Serrano ${ }^{1, *}$, Jesús Sánchez-Martín ${ }^{2}$, José Moreno-Losada ${ }^{1}$ and \\ Francisco Zamora-Polo ${ }^{3}$ \\ 1 Departamento de Didáctica de las Ciencias Sociales, Lengua y Literatura, Facultad de Educación, \\ Universidad de Extremadura, 06006 Badajoz, Spain; jmorenol@unex.es \\ 2 Departamento de Didáctica de las Ciencias Experimentales y Matemáticas, Facultad de Educación, \\ Universidad de Extremadura, 06006 Badajoz, Spain; jsanmar@unex.es \\ 3 Departamento de Ingeniería del Diseño, Escuela Politécnica Superior, Universidad de Sevilla, 41011 \\ Sevilla, Spain; fzpolo@us.es \\ * Correspondence: mariocorralesserrano@gmail.com; Tel.: +34-674964987 \\ + Presented at the 5th Ibero-American Congress on Entrepreneurship, Energy, \\ Environment and Technology-CIEEMAT, Portalegre, Portugal, 11-13 September 2019. \\ Published: 25 December 2019
}

\begin{abstract}
This paper presents an educational experience in the area of learning about Art History, in particular, about the Greco-Roman period, using an innovative resource that is available due to current technology: the virtual visit. This resource allows students to experience immersion in the reconstruction of classic monuments that have deteriorated with time. The combination of current images with this type of virtual visit provides greater ease for understanding the monuments and their function in antiquity, and it is converted into an important motivating factor in the study of this artistic period. The experience has been carried out with 1st year ESO (compulsory secondary education) and 2nd year A-level students, focusing on close context heritage elements, such as the monuments of Mérida or Évora. The results obtained show an increase in the students' interest in this artistic period due to their greater ability to understand the monuments they are studying.
\end{abstract}

Keywords: social science teaching; motivation; virtual reality; art history; heritage

\section{Introduction}

The importance of the use of historical and cultural heritage is supported by numerous studies This underlines the possibilities that heritage resources offer for the acquisition of competencies in the field of Social Sciences [1,2]. For this reason, the use of heritage has become an important trend in the teaching of Social Sciences, as can be appreciated in the textbooks themselves [3,4]. Often, explanations around a historical phenomenon are accompanied by images that represent heritage elements that illustrate the said phenomenon.

If you concentrate on the subject of Art History, this element is even more important, as artistic heritage becomes this subject in the typical material objective of study and not only as a complement, which happens in other Social Science subjects.

Everything that has been explained until now serves to knock down the importance that the current study of historical heritage has for the acquisition of abilities in the field of Social Sciences. However, as it appears in the scientific literature referenced, the use of heritage in the processes of teaching and learning presents many difficulties $[4,5]$. The mark left by the passage of years usually 
makes the complete understanding of ancient buildings enormously more difficult, for example, its possible original state, its usefulness or its aesthetic beauty.

In order to face this difficulty, a tool that is really proving to be useful is the use of the so-called emerging technologies [6], which allow a vision of the heritage, combining the remaining elements with those that have already deteriorated or disappeared but can be technologically reconstructed. In this sense, the use of virtual images is being implemented, which allows the possibility of knowing historical heritage, not only in its current state but also in its original state, offering interesting educational applications, for example, in the knowledge of museum contents [7]. In this field, some experiences such as virtual visits, which recreate historical spaces, can allow students to be immersed in the historic-artistic reality with a more enriched perspective. The present work analyses an experience carried out with this type of virtual visit in the field of Art History.

\section{Experience of the Use of Virtual Visits in the Learning of Historical Heritage}

The use of experiences of virtual coming together to historical heritage presents a series of interesting benefits in the teaching and learning of heritage elements from the ancient period that, due to the passage of time, now cannot be known as they were in their moment of splendour and that, currently, are in a state of decay. Often, the criteria used in the restoration of these heritage elements allow those that have not succumbed to the passing of time to be shown in a consolidated way, but in turn, they do not add those elements that have been destroyed. Therefore, the current view of a monument from the Roman era sometimes differs largely from the aspect that it would have had in its original era.

This fact creates an educational problem because, in order to interpret the remains of an ancient monument adequately, the student must be able to sense elements that are now not in the work or that are too deteriorated. This circumstance creates more difficulty as the fact that there are no actual buildings having the same structure as the deteriorated ones means the student cannot therefore establish comparisons with the present.

To resolve this difficulty, a consistent educational experience has been put in place to complement the display of photographs of heritage elements with the display of videos showing virtual visits to these same reconstructed monuments with digital technology. The hypothesis about what forms this experience is that the combination of both types of getting closer to the heritage provides a better understanding of their technical characteristics, a better understanding of the function of the said heritage in antiquity, and a better ability to empathise with the heritage by the student.

\subsection{Objectives}

The educational objectives that go along with this investigation are the following:

- To assist the learning of abilities related to artistic and cultural heritage from ancient times.

- To test the adequacy of the use of virtual visits in the process of teaching and learning for Social Sciences.

- To explore the possible motivating effects of the use of emerging technologies for students of Social Science subjects.

With the objectives that have been set out, it is hoped that there is an impact on the importance of applying active methodologies in the teaching of Social Sciences to develop their contents practically [8]. These methodologies have an influence on showing the usefulness of the acquired contents in these subjects, favouring the motivation of students.

\subsection{Abilities that Have been Worked on}

The curriculum competencies for the subjects of Geography and History of first year ESO (compulsory secondary education) students that have been worked on in this experience are related to the historical heritage of ancient times, for example, the Greek and Roman civilisations. Table 1 shows the contents as they appear in the subject curriculum: 
Table 1. Curriculum contents referring to Greek and Roman architecture: Source: decree 98/2016.

\begin{tabular}{|c|c|c|}
\hline \multicolumn{3}{|c|}{ Curriculum Contents } \\
\hline Contents & Evaluation Criteria & Assessable Standards \\
\hline $\begin{array}{l}\text { Roman art. Architecture. } \\
\text { Characteristics of the } \\
\text { architecture. } \\
\text { Religious and civil buildings. }\end{array}$ & $\begin{array}{l}\text { To know the legacy of Roman } \\
\text { architecture and to recognise } \\
\text { and discuss significant works. }\end{array}$ & $\begin{array}{l}\text { Know the legacy of } \\
\text { Roman architecture, and } \\
\text { identify and describe } \\
\text { significant works. }\end{array}$ \\
\hline
\end{tabular}

\section{Methodology}

\subsection{Sample}

The experiment has been done with a sample of 62 first year ESO (compulsory secondary education) students, in the subjects Geography and History, who belong to two different groups (30 and 32 students respectively). The most important features of this group of students are the following:

- The distribution of the sample by gender is $49 \%$ boys and $51 \%$ girls.

- If the qualifications of the students in the sample of Geography and History are taken into account, the distribution is the following: $28 \% \mathrm{~A}, 32 \% \mathrm{~B}, 24 \% \mathrm{C}$, and $16 \%$ failed the first round of exams.

- $\quad$ Regarding how much they like the subject, the students in the sample rated their interest in Geography and History between 5 and 7 out of 10 .

- Among both groups, there are 2 students with special educational needs, which have been integrated into the development of the experience.

- For some of the activities of this experience, the students from the sample have been divided into groups of 4 .

\subsection{Phases}

The activity phases were:

- Theoretical phase: this first phase of the experience consisted in the theoretical development of the contents of the curriculum referred to in Table 1, employing a combination of traditional methodologies with active methodology, and with a consistent practical experience in the production of a revision game with the specific characteristics of the different types of buildings based on a gamification methodology [9].

- Photographic phase: Once the content is learnt, a photography activity was proposed to the students, consisting in showing 2 photographs, one of the Roman theatre Mérida and one of the Roman Temple Évora, as they are currently. The selection of these images is due to the proximity of both monuments, just as the familiarity the students have with the said monuments.

- Virtual phase: the students have been shown two virtual visits, one of each of these two monuments, in which they were shown digital reconstructions and recreations of the environments in which the monuments were built. They have also been asked to respond to the same questions: to identify studied artistic elements and to express their opinion.

The display of the image is accompanied by a task that consists of researching the history of both buildings and making a 150 word report about the research, including two questions that the students must answer: Which element of the ancient architecture do you recognise in these images? What do you think of these buildings? Both questions should be answered individually.

In Figure 1 are shown that were provided to the students. 

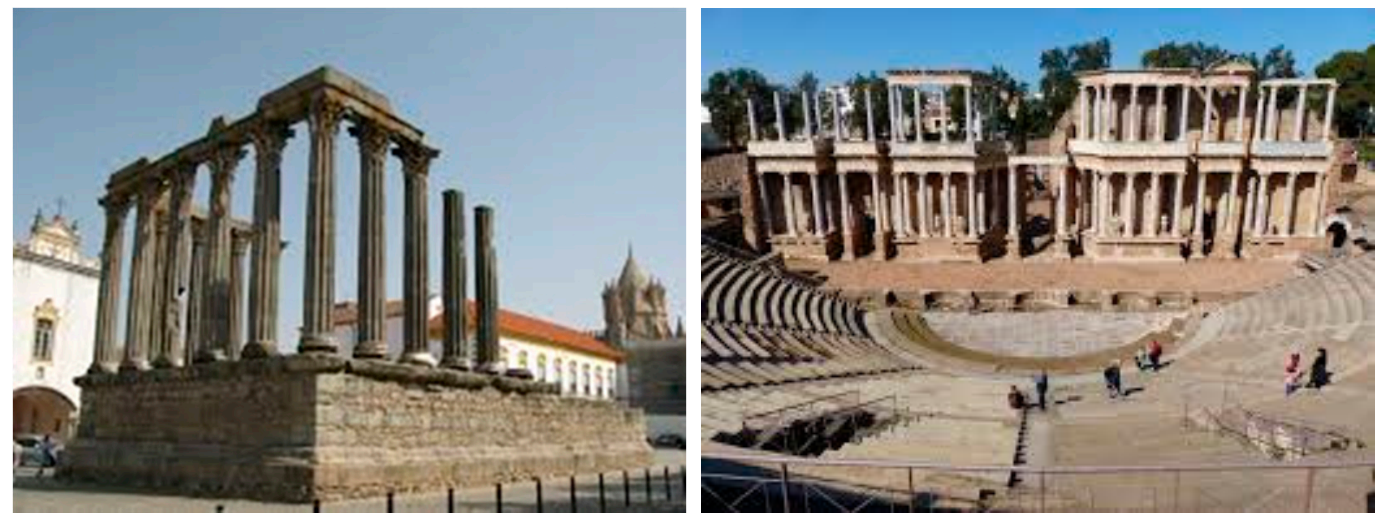

Figure 1. Roman Temple Évora (left); Roman theatre Mérida (right).

\section{Results and Discussion}

The experience carried out has been evaluated based on the curriculum and educational objectives that had been set out, analysing the responses that the students have given to the questions that were asked in the second and third phase of the experience. The categorisation of these results through the qualitative software WebQDA allows, on the one hand, the possible differences between the observations of the main architectural elements in the photography and the virtual visit to be observed and, on the other hand, the valuation that each of the two elements creates in the student.

Some interesting elements were detected in analysis:

- $87 \%$ of the students recognise key architectural elements, such as the style of the building's columns or the type of construction in one of the two phases of the experience.

- Regarding the step from photography to virtual visit, the majority of students $(78 \%)$ do not identify any new architectural elements in the commentary about the virtual visit, that would not have already been observed in the photography commentary, and if they did identify a new element, it referred to nuances about elements that were already identified. Therefore, it can be deduced that both tools are useful in the acquisition of scheduled curriculum abilities.

- Regarding the motivating effect and the creation of empathy for heritage in the students, analysis of the second question done in the two phases (photography and virtual) has been carried out, categorising the texts in reference to two items: "texts that show motivation for study" and "texts that show empathy for heritage". The results show interesting data: the valuation of the monument in the virtual visit receives 46 comments for students that we can categorise into the items of empathy and motivation, but only 19 comments on the photographs.

These results are consistent with some studies that show the usefulness of the application of emerging technologies for the study of heritage [10]. Finally, and given the importance of raising awareness among students of the need to work for a sustainable world [11], we believe that a greater valuation of heritage is important for the development of sustainable communities and cities.

\section{Conclusions}

In light of the results, it can be said that the combination of photography and virtual visits is an appropriate methodology for the learning of abilities related to historical heritage. Regarding the adequacy of the use of virtual visits, on the one hand, the results show an improvement in the acquisition of abilities, even though this improvement is not large. On the other hand, interesting motivating effects are detected in the students, just as a greater creation of empathy for ancient heritage. 


\section{References}

1. Estepa, J.; Wamba, A.M.; Jiménez, R. Fundamentos Para Una Enseñanza y Difusión del Patrimonio Desde Una Perspectiva Integradora de las Ciencias Sociales y Experimentales; Diada Editorial: Barcelona, España, 2005.

2. Masachs, R.C. Un modelo de investigación didáctica del patrimonio. Enseñan. Cienc. Soc. Rev. Investig. 2010, 9, 17-28.

3. Estepa, J.; Ferreras, M.; López, I.; Morón, H. Análisis del patrimonio presente en los libros de texto: Obstáculos, dificultades y propuestas. Rev. Educ. 2011, 355, 573-589. doi:10-4438/1988-592X-RE-2011-355037.

4. Cuenca, J.M.; Estepa, J. El Patrimonio en Las Ciencias Sociales: Concepciones Transmitidas Por Los Libros de Texto de ESO; AUPDCS: Madrid, España, 2003.

5. Estepa, J. El patrimonio en la didáctica de las ciencias sociales: Obstáculos y propuestas para su tratamiento en el aula. Rev. Íber 2001, 30, 5.

6. Gutiérrez, R.; Martínez MBravo, J.; Bravo, J. Tecnologías emergentes para la enseñanza de las Ciencias Sociales. Una experiencia con el uso de Realidad Aumentada en la formación inicial de maestros. Digit. Educ. Rev. 2015, 27, 138-153.

7. Domínguez, P. Museos Virtuales de Pedagogía, Enseñanza y Educación: Hacia una didáctica del patrimonio histórico-educativo. Educ. Artíst. Rev. Investig. 2011, 2, $23-27$.

8. Corrales, M.; Sánchez, J.; Moreno, J.; Zamora, F. Las motivaciones de los jóvenes para el estudio: Raíces y consecuencias. Cuad. Investig. Juv. 2018, 4, 60-79.

9. Candel, E. El uso de la gamificación y los recursos digitales en el aprendizaje de las ciencias sociales en la educación superior. Didáctica Innovación Multimed 2018, 36, 4.

10. Veletsianos, G. Emerging Technologies in Distance Education; Athabasca University Press: Edmonton, AB, Canada, 2010.

11. Zamora-Polo, F.; Sánchez-Martín, J.; Corrales-Serrano, M.; Espejo-Antúnez, L. What Do University Students Know about Sustainable Development Goals? A Realistic Approach to the Reception of this UN Program Amongst the Youth Population. Sustainability 2019, 11, 3533. 